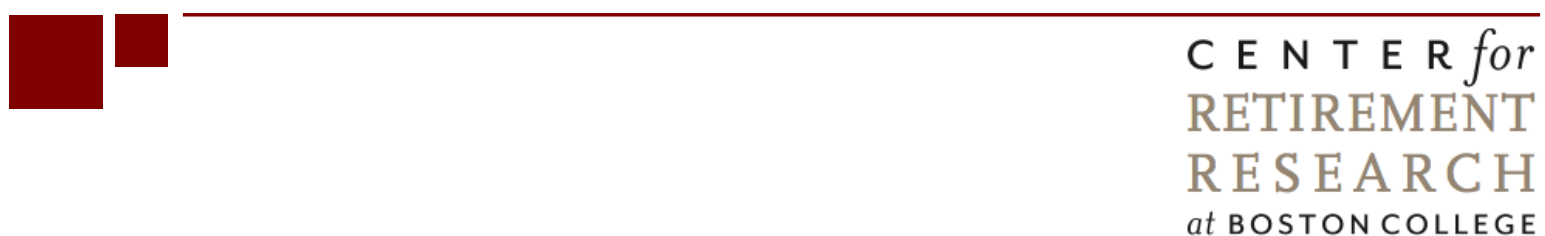

\title{
LIFETIME JOB DEMANDS, WORK CAPACITY AT OLDER AGES, AND SOCIAL SECURITY BENEFIT CLAIMING DECISIONS
}

\author{
Lauren Hersch Nicholas \\ CRR WP 2014-15 \\ Submitted: September 2014 \\ Released: November 2014 \\ Center for Retirement Research at Boston College \\ Hovey House \\ 140 Commonwealth Ave \\ Chestnut Hill, MA 02467 \\ Tel: 617-552-1762 Fax: 617-552-0191 \\ http://crr.bc.edu
}

Lauren Hersch Nicholas is an assistant professor of health policy and management at Johns Hopkins Bloomberg School of Public Health and a surgery faculty associate at the University of Michigan's Survey Research Center. The research reported herein was performed pursuant to a grant from the U.S. Social Security Administration (SSA) funded as part of the Retirement Research Consortium. The opinions and conclusions expressed are solely those of the author and do not represent the opinions or policy of SSA, any agency of the federal government, the Johns Hopkins Bloomberg School of Public Health, the University of Michigan Survey Research Center, or Boston College. Neither the United States Government nor any agency thereof, nor any of their employees, makes any warranty, express or implied, or assumes any legal liability or responsibility for the accuracy, completeness, or usefulness of the contents of this report. Reference herein to any specific commercial product, process or service by trade name, trademark, manufacturer, or otherwise does not necessarily constitute or imply endorsement, recommendation or favoring by the United States Government or any agency thereof. The author would like to acknowledge helpful comments from participants of the 2014 Michigan Retirement Research Center annual conference and excellent research assistance from Nicolae Done and Susan Yeh.

(C) 2014, Lauren Hersch Nicholas. All rights reserved. Short sections of text, not to exceed two paragraphs, may be quoted without explicit permission provided that full credit, including (C) notice, is given to the source. 


\section{About the Steven H. Sandell Grant Program}

This paper received funding from the Steven H. Sandell Grant Program for Junior Scholars in Retirement Research. Established in 1999, the Sandell program's purpose is to promote research on retirement issues by scholars in a wide variety of disciplines, including actuarial science, demography, economics, finance, gerontology, political science, psychology, public administration, public policy, sociology, social work, and statistics. The program is funded through a grant from the Social Security Administration (SSA). For more information on the Sandell program, please visit our website at: http://crr.bc.edu/about-us/grantprograms/stevenhsandell-grant-program-2/ send e-mail to crr@bc.edu, or call (617) 552-1762.

\section{About the Center for Retirement Research}

The Center for Retirement Research at Boston College, part of a consortium that includes parallel centers at the University of Michigan and the National Bureau of Economic Research, was established in 1998 through a grant from the Social Security Administration. The Center's mission is to produce first-class research and forge a strong link between the academic community and decision-makers in the public and private sectors around an issue of critical importance to the nation's future. To achieve this mission, the Center sponsors a wide variety of research projects, transmits new findings to a broad audience, trains new scholars, and broadens access to valuable data sources.

Center for Retirement Research at Boston College

Hovey House

140 Commonwealth Ave

Chestnut Hill, MA 02467

Tel: 617-552-1762 Fax: 617-552-0191

http://crr.bc.edu

Affiliated Institutions:

The Brookings Institution

Massachusetts Institute of Technology

Syracuse University

Urban Institute 


\begin{abstract}
We use Health and Retirement Study data linked to the Department of Labor's O*Net classification system to examine the relationship between lifetime exposure to occupational demands and retirement behavior. We consistently found that both non-routine cognitive analytic and non-routine physical demands were associated with worse health, earlier labor force exit, and increased use of Social Security Disability Insurance. The growing share of workers in jobs with high levels of cognitive demand may contribute to growth in DI use.
\end{abstract}


Work accounts for a significant portion of Americans' daily lives and is increasingly recognized as a determinant of health status. Research dating to the Whitehall study results of the 1970s has shown a relationship between occupation and long-term health outcomes including mortality, diabetes and cardiovascular disease that cannot be explained by differences in income, education, health behaviors or access to health insurance (Marmot et al., 1978). Several studies have found that older workers retire from physically demanding jobs more rapidly than from other types of jobs (i.e. Filer and Petri, 1988; Mitchell et al., 1988; Hayward et al., 1989; Case and Deaton, 2005), but have focused on characteristics of current jobs, which are likely jointly determined with health and labor force status. A growing literature in economics and medicine finds lasting health effects of adverse early life health exposures, including the earliest events experienced in utero (Almond, 2006; Smith, 2009; Almond and Currie, 2011), suggesting that exposure to job demands throughout the lifecourse may influence work capacity and retirement decisions later in life.

In this paper, we examine the relationship between occupational exposures which may harm or hurt health including physical and cognitive job demands on subjective and objective measures of whether health limits an individual's ability to work at various ages, application for and receipt of Disability Insurance (DI) benefits, and age at initial Social Security benefit claiming using lifetime jobs reported by older adult respondents in the Health and Retirement Study. This enables us to assess intensity of exposure that account for the nature of occupational demands and the duration of a worker's exposure to a given characteristic. Our study extends prior research by using a more comprehensive and accurate classification system for job characteristics, accounting for exposure to job characteristics prior to age 50, when most studies of job characteristics and retirement start, and including women, who have traditionally been excluded from many studies in this literature.

\section{Background}

Motivation for this paper comes from two primary literatures; work in economics demonstrating the relationships between health status and work place exits due to disability or early retirement, and an extensive epidemiological and occupational health literature finding relationships between various job characteristics and worker health outcomes. 
Physically demanding jobs can help health through on-the-job exercise, or harm health through stressors such as repetitive motion, lifting or pushing heavy objects, and accidents. Workers in low-skill occupations requiring manual labor report worse self-rated health and higher disease burden than other workers in cross-sectional data (Case and Deaton, 2005). The consequences of occupation for later-life health are potentially large; Costa (2005) estimates that $29 \%$ of the decline in chronic illness among older men from 19001980 was driven by shifts to less physically demanding occupations. The absence of physical activity at work can also harm health; extended sitting and computer use have been linked to back pain, obesity, and elevated cholesterol (Owen et al., 2010).

Recent papers linking job demand data to national surveys including the National Health Interview Study and the National Health and Nutrition Examination Survey find mixed evidence of a contemporaneous association between physically demanding work, hazardous work exposures, and several measures of health and disease. However, these results are likely biased by less healthy workers selecting out of demanding jobs as their health declines, a group of particular interest for Social Security benefit claiming research. The few papers that estimate causal effects of physically demanding occupations focus on a limited number of health outcomes among workers who are largely still employed (Fletcher et al., 2011; Lakdawalla and Philipson, 2007).

Several economics papers have found that older male workers in physically demanding jobs retire earlier than those in non-demanding jobs. Results are consistent across the National Longitudinal Study of Older Men (Hayward et al., 1989); aggregate Census data (Filer and Petri, 1988), and administrative data from a Alcoa, a single large employer (Modrek and Cullen, 2012). In contrast, Hurd and McGarry (1993) found little effect of physically demanding job characteristics on the self-reported probability of working past age 62 or 65 among older workers interviewed in the first wave of the Health and Retirement Study.

Fletcher et al. (2011) use data from the Panel Study of Income Dynamics to study the longerterm effect of job characteristics on health. Their design and findings are particularly relevant to our study. While the papers discussed previously rely on the demands of jobs that workers still hold at ages 50 and above, Fletcher and colleagues assess the cumulative effect of jobs held over 
the past 5 years in a sample of working-aged adults with a mean age of 42 . They find that cumulative exposure to physical demands is associated with non-trivial declines in self-rated health for older (but not younger) men as well as older and younger women. Their results indicate that a 1 standard deviation increase in job physical demands deteriorates health at a magnitude comparable to a 1 to 2 year decrease in years of education. Fletcher et al. do not examine the effects of cognitive demands, nor do they consider the effect of job characteristics on retirement and disability.

\section{Data and Methods}

\subsection{Health and Retirement Study}

We use survey data from the Health and Retirement Study (HRS), a nationally representative, longitudinal study of more than 30,000 older Americans age 51 and above and their spouses (Juster and Suzman, 1995; Sonnega et al., 2014). HRS respondents provide detailed information about current and previous occupations, health, and socioeconomic status, as well as reports from their childhood, demographic and family characteristics. The first cohort of HRS respondents were between the ages of 51-61 in the first baseline year of the study in 1992, an older cohort aged 70 and above entered in 1993. Additional cohorts aged 5161 and 6874 entered in 1998. Since then, younger cohorts enter at age 51 56. Spouses of sample members can enter at any age.

Some HRS respondents are observed during their working years and others enter after retirement. The HRS asks comprehensive questions about the respondents current or most recent job, and up to 3 previous positions held for five years or more at the first interview; those who are working in subsequent interviews are asked about current jobs and any held since the previous interview. ${ }^{1}$ We use these reports to compile job histories including 3-digit occupation codes and for the $91 \%$ of respondents who report at least one job during an HRS interview.

In addition to movement in and out of jobs and the labor force, respondents also provide

\footnotetext{
${ }^{1}$ The earliest waves of the HRS were conducted as two separate studies, the Health and Retirement Study, including respondents age 51 - 61 and the Study of Aging and Health Dynamics, including those 70 and above. The AHEAD initially collected very little job history information, so we are unable to include respondents who dropped out prior to the addition of AHEAD job history in many of our analyses.
} 
comprehensive information about application for and receipt of DI benefits, Social Security benefit claiming, and retirement. Many HRS respondents also answer questions about childhood health, which allow us to control for health conditions that may have influenced initial selection into occupation and continue to affect health and disability over the lifecourse.

\subsection{Occupational Information Network $\left(\mathrm{O}^{*} \mathrm{Net}\right)$}

Although HRS respondents provide some information about the physical and cognitive demands of current jobs held during the survey, no information is collected about the demands in earlier jobs. By the time workers are age-eligible for the HRS, considerable selection out of healthinfluencing jobs may have already occurred. If workers move into jobs that have different demands later in life, studies using current job characteristics may attribute the benefits or harms of a previous job to the current position. We recover characteristics from previous jobs and standardize our reporting of current job demands using $\mathrm{O}^{*} \mathrm{Net}$.

O*Net was developed by the Department of Labor to replace the Dictionary of Occupational Titles as a primary source of job characteristics. It provides job titles and characteristics collected from multiple sources including questionnaires from job incumbents, interviews with organizational representatives, and ratings from occupational analysts. These data report standardized job characteristics for 974 different occupations covering the skills and abilities necessary to perform each job and characteristics of the occupational environment including generalized work activities, work context and tasks. Most of the economics studies discussed above used the DOT measures of occupation rather than the more comprehensive (and recent) O*Net. Though some critics charge that the $\mathrm{O}^{*} \mathrm{Net}$ data understate physical job demands and are more representative of modern desk jobs, a National Academies Panel found that DOT job characteristics were largely incomplete for positions other than manufacturing jobs. Thus relying on the DOT could cause us to inaccurately classify for more than $80 \%$ of jobs reported in the HRS (Tippins and Hilton, 2010).

We linked $\mathrm{O}^{*}$ Net descriptors to the HRS by Standard Occupation Codes, which crosswalk to three digit Census occupation codes available in the HRS. Prior to linking the O*Net to HRS respondents' jobs, we use information about the importance and frequency of a variety of tasks and 
exposure to working conditions to construct a variety of scales classifying job demands developed by Acemoglu and Autor (2011).

- Non-Routine Cognitive Analytical: analyze data, creative thinking, interpreting information

- Non-Routine Cognitive Interpersonal: develop relationships, guide and coach others

- Routine Cognitive Analytical: repeat physical or mental activities, importance of accuracy, structured job

- Routine Manual: pace determined by machinery, operating machines other than vehicles or computers, repetitive motions

- Non-Routine Manual: maneuvering/driving vehicles or equipment, use hands, manual dexterity, spatial orientation

These measures are all standardized to have a mean of 0 and standard deviation of 1 in the full across the $974 \mathrm{O}^{*}$ Net jobs. Since the distribution of workers into job characteristics varies over time, we do not attempt to weight occupations by worker distribution at a given point in time. Generally, a higher, positive score indicates a higher level of the characteristic in an occupation, while negative scores indicate low levels.

We are able to match at least one job to its $\mathrm{O}^{*} \mathrm{Net}$ characteristics for 26,048 respondents representing a total of 55,456 jobs. We exclude 2,953 respondents who report job tenures for exceeding the oldest age that they are observed in the HRS minus six years plus years of education reported, and 87 respondents reporting jobs with negative tenure, resulting in a sample of 23,008 respondents with plausible occupational tenure. Although HRS does not collect detailed information about all jobs worked by respondents (for example jobs worked prior to the first interview in addition to the up to three five or more years jobs collected at the baseline interview), total years worked and total number of jobs are available. On average, HRS respondents report 2.3 jobs during their lifetime. We have occupational codes for 1.80 of these. Total tenure averages 32.7 years in the main sample, on average we observe job characteristics for jobs worked in 21.5 of these years. 
We conduct a number of analyses in the 11,260 respondents who have linked data for at least 75\% of their total years worked. ${ }^{2}$

We first describe the correlation in job demands across jobs in the subset of respondents reporting three or more jobs. If workers tend to specialize in a type of job characterized by constant characteristics over the lifecourse, knowing characteristics of a job held later in life may be sufficient to describe lifetime exposure. As Table 1 shows, characteristic intensity across lifetime jobs are typically correlated, but not perfectly correlated. For example, the correlation between level of non-routine cognitive analytical demands is 0.55 between the first and second jobs and 0.47 between first and third, for routine manual demands $\rho_{1,2}=0.58$ and $\rho_{1,2}=0.50$. We obtained similar results for $\rho_{1,2}$ in the sample that only has two lifetime jobs and similar results for the other job characteristics that are not reported.

Tables 2 and 3 describe characteristics of the HRS job history sample. Table 2 stratifies by HRS entry cohort and shows that cumulative exposure to routine and non-routine physical demands has been decreasing over time, while exposure to routine and non-routine cognitive demands are increasing. Table 3 stratifies by gender and includes the subset of respondents who have occupational codes for at least $75 \%$ of their total years worked-in this subsample we observe $95 \%$ of lifetime employment. Men have greater exposure to physically demanding jobs in terms of the average and cumulative intensity of characteristics over all jobs reported. $14 \%$ of the sample applies for DI at some point and 10\% receives DI benefits, with slightly higher application and receipt rates among men. Younger cohorts report higher rates of DI application, younger age at first Social Security benefit receipt (including DI benefits), and younger retirement age. This reflects both population-level trends and sample composition- the youngest members of the midBaby Boomers cohort were only 51 at their first interview in 2010. Since reporting retirement age is conditional on retirement, we only see values for those who retire at relatively young ages in the youngest cohorts.

\footnotetext{
${ }^{2}$ Because of missing $\mathrm{O}^{*} \mathrm{Net}$ data and missing child health status or outcome data, our preferred specifications include fewer than 11,260 observations.
} 


\subsection{Estimation Strategy}

Our empirical approach is similar to Filer and Petri (1988) Fletcher et al. (2011). We first consider the relationship between cumulative exposure to job characteristics and Social Security claiming decisions including whether a respondent ever applies for or receives DI, age benefits are first claimed, and age at retirement by estimating ordinary least squares regressions:

$$
\Delta Y_{i}=\alpha \sum J_{i} * T+\beta X_{i}+Y O B+\epsilon_{i}
$$

where $J_{i}$ is a vector of job characteristics, T is a respondent's tenure at each reported job, $X_{i}$ is a vector of respondent characteristics including sex, race, birth cohort, educational attainment, and self-reported health as a child, ${ }^{3}$ and YOB is a vector of year of birth dummy variables. We estimate Equation 1 for the full sample and separately by gender, since both occupation choices and work decisions differ for men and women as Table 3 shows.

In addition to studying respondents' actual decisions around DI and old-age benefits, we consider their physical capacity for work at various ages. We assess this using respondent's self reports at 4 different ages $(62,65,70$, and 75$)$ of whether they have a health condition that limits their ability to work. However, response to this subjective question may be biased by a respondent's current employment situation. Thus, we follow Bound (1991) and also construct an objective measure of health limitations, a summary health measure based on the respondent's actual health conditions. This is a continuous variable based on the predictions from a probit regression of whether health limits work on categories of self-rated health, indicators of whether a respondent has ever been diagnosed with arthritis, cancer, diabetes, heart disease, lung disease, or stroke, and a count of fine motor limitations (difficulties picking up a dime, dressing, or eating). The predicted measure is correlated with self-reports of work limitation ( $\rho=0.60$ across all 4 age-specific samples).

We reestimate Equation 1 replacing the Social Security outcomes $Y_{i}$ with a series of variables $H_{i t}$ capturing self-reported and objective work-limiting health conditions at the four ages previ-

\footnotetext{
${ }^{3}$ We consider specifications with and without childhood health, since early life health problems may constrain educational or occupational choices and in more extreme cases foreshadow DI participation
} 
ously described.

\section{Results}

We first consider the cumulative effect of exposure to physical and cognitive job demands. In these specifications, the $\sum J_{i} * T$ can be large because of a high level of job demand over a relatively short time or sustained exposure to a moderate demand. In these specifications, we find that both non-routine cognitive demands and non-routine manual-physical demands are associated with increased DI application and receipt and earlier retirement and SS claiming (Table 4).

In regressions that instead use the average exposure characteristics in year worked, non-routine cognitive demands switch signs now indicate later retirement and lower probability of DI application or receipt. Non-routine cognitive interpersonal demands and both routine and non-routine demands are associated with increases in DI application and receipt and earlier work force exit, consistent with other studies. Similar to Flethcer et al., we find non-trivial effects of physically demanding work- a one standard deviation increase in routine physical demands increases the probability of DI application by 2.8 percentage points and receipt by 1.7 pp (increases of 19 and $17 \%$ of respective means). A one standard deviation increase in non-routine cognitive analytic demands increases age Social Security benefits are first claimed by 0.5 years and routine cognitive demands by 0.29 . In contrast, graduating high school (compared with less than high school) delays claiming by 0.08 years and college by 0.56 years.

Tables 5 and 6 estimate Equation 1 separately by gender. For men, cumulative exposure to both non-routine cognitive analytical demands and non-routine physical demands are associated with increased DI application and receipt as well as earlier retirement and SS benefit claiming. Other job demands do not appear to be significant determinants of men's DI or retirement decisions. However, the average exposure regressions find no effects of any of the cognitive demands, though routine physical demands continue to predict DI application and receipt and non-routine physical demands are associated with earlier Social Security benefit claiming.

There is little consistent evidence that job demands influence DI and benefit claiming for women. Only non-routine physical job demands are consistently related to DI receipt when we 
consider both cumulative and average exposures. Average exposure to non-routine cognitive demands has a large (3.5 percentage point), negative effect on DI application and receipt, but there is no effect of cumulative exposure.

These analyses include the implicit assumption that that physical and cognitive occupational stressors degrade workers' health, leading to earlier workforce exit. To test this model, we also examine physical capacity for work at older ages by looking at whether respondents self-report that their health limits work. The effects of cumulative and mean exposure are reported in Tables 7 and 8 . Across all ages considered, whether we use self-reported or the more objective predicted measure of health conditions that limit work capacity, we find that greater exposure to both non-routine cognitive analytical and non-routine physical job demands are associated with higher rates of health health limitations. Only average exposure to non-routine physical demands are consistently and significantly associated with health limitations in later life.

\subsection{Robustness}

We examined the sensitivity of our findings to a variety of sample compositions and to alternative measures of job demands previously used in the occupational health literature (i.e Bell et al., 2008; Pransky et al., 2005a, b; Verma et al., 2008). We found very similar results when we used a number of other definitions of physical job demands and cognitive stressors. Our results were also robust across numerous sample specifications. Our preferred specifications include the sample on whom we have the most comprehensive information. However, we obtain similar results when we include respondents whose jobs are missing $\mathrm{O}^{*} \mathrm{Net}$ data and cannot be classified, and when we include respondents who have job characteristics for less than $75 \%$ of their total tenure. Tables A1 and A2 include progressively more observations with missing information about job characteristics. Coefficients are slightly smaller in magnitude compared to our comprehensive information specification in Table 4 but tell a similar story.

An alternative set of job characteristic demands continues to reveal a positive relationship between both cumulative and average physical demands and DI application and receipt (Table A3). Exposure to hazardous conditions also increases SSDI application/recepit and lowers retire- 
ment and benefit claiming ages on average, while greater status recognition moves in the opposite direction. We obtain similar results for work-limiting health conditions in models that include respondents with missing $\mathrm{O}^{*}$ Net characteristics (Table A4).

\section{Conclusions}

We assessed the cumulative effect of job demands on health and retirement outcomes later in life. Using comprehensive data form the Health and Retirement Study and O*Net, we consistently found that both non-routine cognitive analytic and non-routine physical demands were associated with worse health, earlier labor force exit, and increased use of Disability Insurance. Findings support growing concern that both physical and cognitive stressors in the work place can adversely impact employee health. Since workers are increasingly concentrating in jobs with higher levels of cognitive demands, this may be a promising area for job resign or other interventions to reduce this health impact.

Methodologically, this paper highlights the importance of having numerous ways of measuring occupational exposure- in some cases our results change sign when we move from average to cumulative exposure to a given job characteristic. This may reflect the increasing level of selection into job characteristics over time- those are who are still working in physically demanding jobs after multiple years of of exposure are likely healthiest, and able to retire at later ages, which those who are quickly harmed by physical or cognitive demands early on leave the work force after high average exposure to a given characteristic. 


\section{References}

Acemoglu D, Autor DH. Skills, Tasks and Technologies: Implications for Employment and Earnings. Handbook of Labor Economics Volume 4b. Amsterdam: Elsevier, 2011.

Almond D. Is the 1918 Influenza Pandemic Over? Long-Term Effects of In Utero Influenza Exposure in the Post-1940 U.S. Population. Journal of Political Economy. 2006;114(4):672-712.

Almond D, Currie J. Killing me softly: The fetal origins hypothesis. The Journal of Economic Perspectives. 2011:153-172.

Bell, JF, Zimmerman FJ, Diehr PK. Maternal work and birth outcome disparities. Maternal and child health journal, 2008; 12(4), 415-426.

Blekesaune M, Solem PE. Working Conditions and Early Retirement: A Prospective Study of Retirement Behavior. Research on Aging. 2005;27(1):3-30.

Bound J. Self-Reported Versus Objective Measures of Health in Retirement Models. The Journal of Human Resources. 1991;26(1):106-138.

Case A, Deaton A. Broken down by work and sex: How our health declines. Wise DA, editor. Chicago: Univ Chicago Press; 2005

Costa DL. Causes of improving health and longevity at older ages: a review of the explanations. Genus. 2005;61(1):21-38.

Crouter AC, Lanza ST, Pirretti A, Goodman, WB, Neebe E. (2006). The O* Net jobs classification system: A primer for family researchers. Family Relations, 55(4), 461-472.

Filer RK, Petri PA. A Job-Characteristics Theory of Retirement. The Review of Economics and Statistics. 1988;70(1):123-128.

Fletcher JM, Sindelar JL. Estimating Causal Effects of Early Occupational Choice on Later Health: Evidence Using the PSID. National Bureau of Economic Research Working Paper Series. 2009;No. 15256.

Fletcher JM, Sindelar JL, Yamaguchi S. Cumulative effects of job characteristics on health. Health Economics. 2011;20(5):553-70.

Hayward MD, Grady WR, Hardy MA, Sommers D. Occupational Influences on Retirement, Disability, and Death. Demography. 1989;26(3):393-409. 
Juster FT, Suzman R. An overview of the Health and Retirement Study. The Journal of Human Resources. 1995;30:7-56.

Kivimki M, Nyberg ST, Batty GD, et al. Job strain as a risk factor for coronary heart disease: a collaborative meta-analysis of individual participant data. The Lancet. 2012.

Marmot MG, Rose G, Shipley M, Hamilton PJ. Employment grade and coronary heart disease in British civil servants. Journal of Epidemiology and Community Health. 1978;32(4):244-9.

Mitchell OS, Levine PB, Pozzebon S. Retirement Differences by Industry and Occupation. The Gerontologist. 1988;28(4):545-51.

Owen N, Healy GN, Matthews CE, Dunstan DW. Too much sitting: the population health science of sedentary behavior. Exercise Sport Science Review. 2010;38(3):105-13.

Peterson NG, Mumford MD, Borman WC, Jeanneret PR, Fleishman EA, Levin KY, et al. Understanding Work Using The Occupational Information Network (O*NET): Implications For Practice And Research. Personnel Psychology. 2001;54(2):451-92.

Pransky GS, Benjamin KL, Savageau JA, Currivan D, Fletcher K. Outcomes in work-related injuries: A comparison of older and younger workers. American Journal of Industrial Medicine. 2005;47(2):104-112.

Pransky GS, Benjamin KL, Savageau JA. (2005). Early retirement due to occupational injury: Who is at risk?. American journal of industrial medicine,47(4), 285-295.

Rohwedder S, Willis RJ. Mental Retirement. Journal of Economic Perspectives. 2010;24(1):119138.

Smith JP. The Impact of Childhood Health on Adult Labor Market Outcomes. Review of Economics and Statistics. 2009;91(3):478-489.

Sonnega A, Faul JD, Ofstedal MB, Langa KM, Phillips JW, Weir DR. Cohort Profile: the Health and Retirement Study (HRS). International Journal of Epidemiology. 2014;43(2):576-585.

Tippins NT, Hilton ML, editors. A Database for a Changing Economy: Review of the Occupational Information Network (O*NET). Panel to Review the Occupational Information Network (O*NET). Washington, DC: The National Academies Press; 2010.

Verma SK, Sorock GS, Pransky GS, Courtney TK, Smith GS. (2007). Occupational physical 
demands and same-level falls resulting in fracture in female workers: an analysis of workers compensation claims. Injury prevention, 13(1), 32-36. 
Table 1: Correlation of Selected Job Demands Across Jobs within Workers with 3 or More Lifetime Jobs

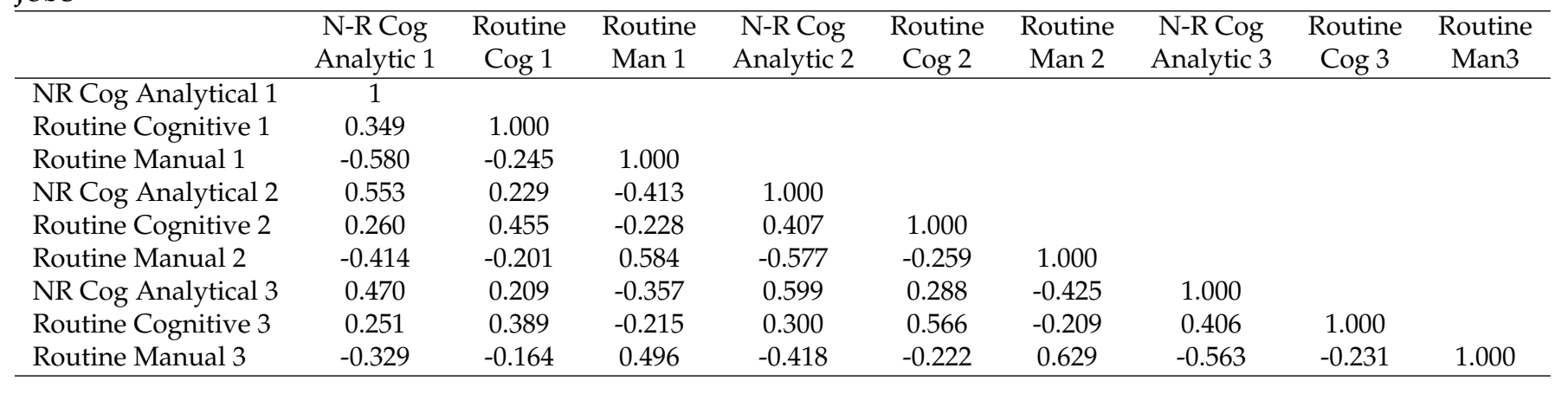


Table 2: Summary Statistics by Health and Retirement Study Age Cohort

\begin{tabular}{|c|c|c|c|c|c|c|c|}
\hline & AHEAD & CODA & HRS & WB & EBB & MBB & Total \\
\hline \multirow[t]{2}{*}{ Ever applied for DI } & 0.044 & 0.064 & 0.194 & 0.203 & 0.145 & 0.110 & 0.150 \\
\hline & $(0.204)$ & $(0.244)$ & $(0.396)$ & $(0.403)$ & $(0.352)$ & $(0.312)$ & $(0.357)$ \\
\hline \multirow{2}{*}{ Ever received DI } & 0.033 & 0.049 & 0.132 & 0.155 & 0.095 & 0.072 & 0.103 \\
\hline & $(0.179)$ & $(0.216)$ & $(0.338)$ & $(0.362)$ & $(0.294)$ & $(0.259)$ & $(0.304)$ \\
\hline \multirow[t]{2}{*}{ SS Claim Age } & 63.98 & 62.82 & 61.51 & 59.51 & 53.96 & 47.76 & 60.88 \\
\hline & $(6.546)$ & $(4.880)$ & $(4.745)$ & $(6.755)$ & $(8.235)$ & $(9.096)$ & $(6.036)$ \\
\hline \multirow{2}{*}{ Age Retired } & 67.819 & 64.040 & 60.764 & 57.086 & 53.849 & 48.660 & 60.60 \\
\hline & (8.194) & (7.069) & $(6.920)$ & (7.119) & $(6.307)$ & (7.438) & (8.099) \\
\hline Total Non-Routine & -8.225 & -6.454 & -8.324 & -5.834 & -5.018 & -2.511 & -6.527 \\
\hline Cog Analytical & $(19.454)$ & (19.084) & $(18.067)$ & $(17.645)$ & (14.193) & $(11.120)$ & $(16.891)$ \\
\hline Total Non-Routine & -2.683 & -0.925 & -1.777 & -0.342 & 0.248 & 1.234 & -0.882 \\
\hline Cog Interperson & $(20.047)$ & (20.700) & $(18.668)$ & (18.128) & (16.413) & (14.184) & $(17.981)$ \\
\hline Total Routine & -1.920 & -1.558 & -2.996 & -2.039 & -1.534 & -0.293 & -2.051 \\
\hline Cognitive & $(17.222)$ & $(16.296)$ & (15.107) & (15.068) & $(12.613)$ & $(9.205)$ & $(14.286)$ \\
\hline Total Routine & 1.766 & 1.112 & 2.332 & 0.255 & 0.407 & -0.065 & 1.343 \\
\hline Manual & (18.519) & (17.909) & $(17.530)$ & $(16.424)$ & $(13.649)$ & $(9.800)$ & $(16.021)$ \\
\hline Total Non-Routine & -1.164 & -1.384 & -0.569 & -2.232 & -1.705 & -1.125 & -1.076 \\
\hline Manual/Physical & $(19.293)$ & (19.225) & (18.343) & $(18.046)$ & (14.797) & $(11.145)$ & $(17.001)$ \\
\hline Mean Non-Routine & -0.380 & -0.331 & -0.400 & -0.302 & -0.316 & -0.213 & -0.342 \\
\hline Cog Analytical & $(0.702)$ & $(0.727)$ & $(0.683)$ & $(0.685)$ & $(0.680)$ & $(0.627)$ & $(0.682)$ \\
\hline Mean Non-Routine & -0.134 & -0.070 & -0.108 & -0.039 & -0.026 & 0.026 & -0.068 \\
\hline Cog Interperson & $(0.744)$ & $(0.785)$ & $(0.717)$ & $(0.710)$ & $(0.744)$ & $(0.734)$ & $(0.733)$ \\
\hline Mean Routine & -0.120 & -0.093 & -0.156 & -0.121 & -0.127 & -0.061 & -0.125 \\
\hline Cogntive & $(0.674)$ & $(0.643)$ & $(0.608)$ & $(0.620)$ & $(0.617)$ & $(0.543)$ & $(0.610)$ \\
\hline Mean Routine & 0.060 & 0.035 & 0.097 & 0.009 & 0.021 & 0.003 & 0.055 \\
\hline Manual & $(0.691)$ & $(0.664)$ & $(0.659)$ & $(0.647)$ & $(0.622)$ & $(0.520)$ & $(0.636)$ \\
\hline Mean Non-Routine & -0.082 & -0.095 & -0.042 & -0.106 & -0.094 & -0.069 & -0.067 \\
\hline Manual/Physical. & $(0.700)$ & $(0.698)$ & $(0.678)$ & $(0.684)$ & $(0.653)$ & $(0.565)$ & $(0.661)$ \\
\hline \multirow[t]{2}{*}{ Tenure w Occ Codes } & 23.862 & 23.053 & 23.458 & 22.362 & 18.870 & 15.995 & 21.461 \\
\hline & $(13.605)$ & $(12.961)$ & $(13.009)$ & $(12.048)$ & $(10.568)$ & $(9.471)$ & $(12.464)$ \\
\hline \multirow[t]{2}{*}{ Total Tenure } & 40.722 & 39.557 & 35.586 & 34.785 & 28.646 & 20.254 & 32.731 \\
\hline & $(14.725)$ & $(13.902)$ & (13.714) & (11.539) & $(11.640)$ & $(9.957)$ & (14.333) \\
\hline \multirow[t]{2}{*}{ Jobs w Occ Codes } & 1.213 & 1.366 & 2.068 & 2.140 & 1.728 & 1.541 & 1.805 \\
\hline & $(0.489)$ & $(0.659)$ & $(1.146)$ & $(1.149)$ & $(0.761)$ & $(0.515)$ & $(0.982)$ \\
\hline \multirow{2}{*}{ Total Jobs } & 2.046 & 2.152 & 2.435 & 2.484 & 2.196 & 2.121 & 2.294 \\
\hline & $(1.382)$ & $(1.346)$ & $(1.490)$ & $(1.505)$ & $(1.345)$ & $(1.293)$ & $(1.427)$ \\
\hline $\mathrm{N}$ & 2,062 & 1,775 & 10,145 & 1,761 & 3,513 & 3,752 & 23,008 \\
\hline
\end{tabular}


Table 3: Summary Statistics by Gender: HRS Respondents with Occupation Codes for at Least $75 \%$ of Lifetime Job Tenure

\begin{tabular}{lccc}
\hline & Male & Female & Total \\
\hline Ever Apply DI & 0.15 & 0.13 & 0.14 \\
Ever Get DI & 0.11 & 0.09 & 0.10 \\
Social Security Claiming Age & 60.94 & 60.24 & 60.62 \\
Retirement Age & 60.08 & 59.94 & 60.01 \\
Total NR Cognitive Analytical & -10.97 & -8.02 & -9.42 \\
Total NR Cognitive Interpersonal & -2.63 & 0.18 & -1.15 \\
Total Routine Cognitive & -4.78 & -1.70 & -3.12 \\
Total Routine Manual & 8.52 & -2.33 & 2.72 \\
Total Non-Routine Manual/Physical & 7.84 & -8.61 & -0.98 \\
Mean NR Cognitive Analytical & -0.38 & -0.36 & -0.37 \\
Mean NR Cognitive Interpersonal & -0.11 & -0.02 & -0.06 \\
Mean Routine Cognitive & -0.18 & -0.11 & -0.14 \\
Mean Routine Physical & 0.28 & -0.07 & 0.10 \\
Mean NR Manual/Physical & 0.26 & -0.32 & -0.05 \\
Total tenure w Occ Codes & 30.42 & 24.31 & 27.33 \\
Total Jobs w Occ Codes & 1.69 & 1.81 & 1.75 \\
Age at last interview & 65.27 & 63.60 & 64.43 \\
Black & 0.18 & 0.24 & 0.21 \\
Hispanic & 0.12 & 0.13 & 0.13 \\
Education (years) & 12.18 & 12.50 & 12.34 \\
Very good health as a child & 0.28 & 0.27 & 0.27 \\
Good health as a child & 0.15 & 0.16 & 0.16 \\
Fair health as a child & 0.04 & 0.05 & 0.05 \\
Poor health as a child & 0.02 & 0.02 & 0.02 \\
\hline N & 5,557 & 5,703 & 11,260 \\
\hline
\end{tabular}


Table 4: Effects of Exposure to Job Characteristics, Disability and Retirement Outcomes: Pooled Sample

\begin{tabular}{|c|c|c|c|c|c|c|c|c|}
\hline \multirow{3}{*}{ Total N-R Cog Analytical } & \multicolumn{2}{|c|}{ Ever Apply DI } & \multicolumn{2}{|c|}{ Ever Get DI } & \multicolumn{2}{|c|}{ Age SS Claiming } & \multicolumn{2}{|c|}{ Age Retired } \\
\hline & $0.000803^{* * *}$ & & $0.000513^{* *}$ & & $-0.0134^{* *}$ & & $-0.0380^{* * *}$ & \\
\hline & $(0.000275)$ & & $(0.000238)$ & & $(0.00573)$ & & $(0.00690)$ & \\
\hline \multirow[t]{2}{*}{ Total NR Cog Interperson } & -0.000113 & & $9.15 \mathrm{e}-05$ & & 0.00386 & & 0.00174 & \\
\hline & $(0.000224)$ & & $(0.000194)$ & & $(0.00473)$ & & $(0.00574)$ & \\
\hline \multirow[t]{2}{*}{ Total Routine Cognitive } & $2.62 \mathrm{e}-05$ & & $5.69 \mathrm{e}-05$ & & 0.00618 & & $-0.00920^{*}$ & \\
\hline & $(0.000215)$ & & $(0.000186)$ & & $(0.00449)$ & & $(0.00537)$ & \\
\hline \multirow[t]{2}{*}{ Total Routine Manual } & 0.000444 & & 0.000300 & & -0.00558 & & -0.000525 & \\
\hline & $(0.000337)$ & & $(0.000292)$ & & $(0.00674)$ & & $(0.00826)$ & \\
\hline \multirow[t]{2}{*}{ Total NR Manual } & $0.000859^{* * *}$ & & $0.000861^{* * *}$ & & -0.00525 & & $-0.0189^{* * *}$ & \\
\hline & $(0.000285)$ & & $(0.000247)$ & & $(0.00578)$ & & $(0.00707)$ & \\
\hline \multirow[t]{2}{*}{ Mean NR Cog Analytical } & & $-0.0167^{*}$ & & $-0.0165^{* *}$ & & $0.504^{* *}$ & & 0.108 \\
\hline & & $(0.00875)$ & & $(0.00758)$ & & $(0.203)$ & & $(0.244)$ \\
\hline \multirow[t]{2}{*}{ Mean NR Cog Interpersonal } & & $0.0119^{*}$ & & $0.0154^{* * *}$ & & -0.253 & & $-0.530^{* * * *}$ \\
\hline & & $(0.00690)$ & & $(0.00598)$ & & $(0.164)$ & & $(0.197)$ \\
\hline \multirow{2}{*}{ Mean Routine Cogntive } & & -0.00533 & & -0.00217 & & $0.288^{*}$ & & -0.165 \\
\hline & & $(0.00639)$ & & $(0.00553)$ & & $(0.147)$ & & $(0.175)$ \\
\hline \multirow[t]{2}{*}{ Mean Routine Manual } & & $0.0282^{* * *}$ & & $0.0174^{* *}$ & & -0.318 & & -0.364 \\
\hline & & $(0.0102)$ & & $(0.00884)$ & & $(0.223)$ & & $(0.276)$ \\
\hline \multirow[t]{2}{*}{ Mean NR Manual } & & $0.0155^{*}$ & & $0.0191^{* *}$ & & 0.0469 & & -0.0456 \\
\hline & & $(0.00882)$ & & $(0.00764)$ & & $(0.197)$ & & $(0.241)$ \\
\hline \multirow[t]{2}{*}{ Black } & $0.0791^{* * *}$ & $0.0698^{* * *}$ & $0.0445^{* * *}$ & $0.0378^{* * *}$ & $-0.979^{* * *}$ & $-0.792^{* * *}$ & $-0.697^{* * *}$ & $-0.498^{*}$ \\
\hline & $(0.00968)$ & $(0.00973)$ & $(0.00838)$ & $(0.00842)$ & $(0.227)$ & $(0.228)$ & $(0.270)$ & $(0.273)$ \\
\hline \multirow[t]{2}{*}{ Hispanic } & $-0.0381^{* * *}$ & $-0.0444^{* * *}$ & $-0.0410^{* * *}$ & $-0.0455^{* * *}$ & 0.0969 & 0.185 & 0.261 & 0.338 \\
\hline & $(0.0130)$ & $(0.0131)$ & $(0.0113)$ & $(0.0113)$ & $(0.327)$ & $(0.327)$ & $(0.413)$ & $(0.416)$ \\
\hline \multirow[t]{2}{*}{ High School Grad } & $-0.0686^{* * *}$ & $-0.0592^{* * *}$ & $-0.0444^{* * *}$ & $-0.0381^{* * *}$ & 0.242 & 0.0822 & 0.0425 & -0.0936 \\
\hline & $(0.0110)$ & $(0.0110)$ & $(0.00948)$ & $(0.00954)$ & $(0.231)$ & $(0.233)$ & $(0.288)$ & $(0.292)$ \\
\hline \multirow[t]{2}{*}{ College +} & $-0.106^{* * *}$ & $-0.0798^{* * *}$ & $-0.0695^{* * *}$ & $-0.0514^{* * *}$ & $1.024^{* * *}$ & $0.563^{* *}$ & $1.088^{* * *}$ & $0.602^{*}$ \\
\hline & $(0.0120)$ & $(0.0123)$ & $(0.0104)$ & $(0.0106)$ & $(0.263)$ & $(0.271)$ & $(0.322)$ & $(0.334)$ \\
\hline Observations & 7,910 & 7,910 & 7,910 & 7,910 & 3,765 & 3,765 & 4,361 & 4,361 \\
\hline
\end{tabular}

Standard errors in parentheses. ${ }^{*} \mathrm{p}<0.10,{ }^{* *} \mathrm{p}<0.05,{ }^{* * *} \mathrm{p}<0.01$. HRS respondents with $75+\%$ of job tenure linked to $\mathrm{O}^{*} \mathrm{Net}$ job characteristics. Regressions also control for HRS birth cohort, year of birth indicators, child health, and missing race/ethnicity. 
Table 5: Effects of Exposure to Job Characteristics, Disability and Retirement Outcomes: Men

\begin{tabular}{|c|c|c|c|c|c|c|c|c|}
\hline \multirow{3}{*}{ Total N-R Cog Analytical } & \multicolumn{2}{|c|}{ Ever Apply DI } & \multicolumn{2}{|c|}{ Ever Get DI } & \multicolumn{2}{|c|}{ Age SS Claiming } & \multicolumn{2}{|c|}{ Age Retired } \\
\hline & $0.00153^{* * *}$ & & $0.00118^{* * *}$ & & $-0.0275^{* * *}$ & & $-0.0651^{* * *}$ & \\
\hline & $(0.000437)$ & & $(0.000376)$ & & $(0.0103)$ & & $(0.0116)$ & \\
\hline \multirow[t]{2}{*}{ Total NR Cog Interperson } & -0.000443 & & -0.000308 & & 0.0120 & & $0.0209^{* *}$ & \\
\hline & $(0.000338)$ & & $(0.000291)$ & & $(0.00808)$ & & $(0.00926)$ & \\
\hline \multirow[t]{2}{*}{ Total Routine Cognitive } & -0.000159 & & $2.56 \mathrm{e}-05$ & & 0.00243 & & $-0.0168^{* *}$ & \\
\hline & $(0.000281)$ & & $(0.000242)$ & & $(0.00663)$ & & $(0.00745)$ & \\
\hline \multirow[t]{2}{*}{ Total Routine Manual } & 0.000562 & & 0.000754 & & 0.00841 & & $0.0243^{*}$ & \\
\hline & $(0.000544)$ & & $(0.000468)$ & & $(0.0123)$ & & $(0.0144)$ & \\
\hline \multirow[t]{2}{*}{ Total NR Manual } & $0.00151^{* * *}$ & & $0.000924^{* *}$ & & $-0.0515^{* * *}$ & & $-0.0729^{* * *}$ & \\
\hline & $(0.000536)$ & & $(0.000461)$ & & $(0.0123)$ & & $(0.0145)$ & \\
\hline \multirow[t]{2}{*}{ Mean NR Cog Analytical } & & 0.00573 & & 0.00373 & & 0.379 & & 0.0594 \\
\hline & & $(0.0128)$ & & $(0.0110)$ & & $(0.337)$ & & $(0.379)$ \\
\hline \multirow[t]{2}{*}{ Mean NR Cog Interpersonal } & & 0.00530 & & 0.00614 & & -0.271 & & -0.407 \\
\hline & & $(0.00962)$ & & $(0.00827)$ & & $(0.257)$ & & $(0.294)$ \\
\hline \multirow[t]{2}{*}{ Mean Routine Cognitive } & & -0.0105 & & -0.00293 & & 0.0612 & & -0.341 \\
\hline & & $(0.00784)$ & & $(0.00674)$ & & $(0.204)$ & & $(0.229)$ \\
\hline \multirow[t]{2}{*}{ Mean Routine Manual } & & $0.0441^{* * *}$ & & $0.0338^{* * *}$ & & 0.0624 & & -0.0747 \\
\hline & & $(0.0147)$ & & $(0.0127)$ & & $(0.358)$ & & $(0.432)$ \\
\hline \multirow[t]{2}{*}{ Mean NR Manual } & & 0.00490 & & $-8.59 \mathrm{e}-05$ & & $-0.809^{* *}$ & & -0.294 \\
\hline & & $(0.0157)$ & & $(0.0135)$ & & $(0.390)$ & & $(0.469)$ \\
\hline \multirow[t]{2}{*}{ Black } & $0.0738^{* * *}$ & $0.0695^{* * *}$ & $0.0430^{* * *}$ & $0.0406^{* * *}$ & -0.453 & -0.398 & -0.0639 & 0.0409 \\
\hline & $(0.0123)$ & $(0.0123)$ & $(0.0105)$ & $(0.0106)$ & $(0.318)$ & $(0.320)$ & $(0.364)$ & $(0.370)$ \\
\hline \multirow[t]{2}{*}{ Hispanic } & $-0.0525^{* * *}$ & $-0.0557^{* * *}$ & $-0.0305^{* *}$ & $-0.0325^{* *}$ & -0.262 & -0.295 & 0.657 & 0.715 \\
\hline & $(0.0168)$ & $(0.0169)$ & $(0.0144)$ & $(0.0145)$ & $(0.469)$ & $(0.473)$ & $(0.562)$ & $(0.571)$ \\
\hline \multirow[t]{2}{*}{ High School Grad } & $-0.0807^{* * *}$ & $-0.0769^{* * *}$ & $-0.0348^{* * *}$ & $-0.0347^{* * *}$ & 0.149 & 0.152 & 0.121 & 0.178 \\
\hline & $(0.0146)$ & $(0.0147)$ & $(0.0125)$ & $(0.0126)$ & (0.338) & $(0.344)$ & (0.409) & $(0.420)$ \\
\hline \multirow[t]{2}{*}{ College + } & $-0.116^{* * *}$ & $-0.101^{* * *}$ & $-0.0570^{* * *}$ & $-0.0516^{* * *}$ & $0.653^{*}$ & 0.505 & $0.784^{*}$ & 0.580 \\
\hline & $(0.0159)$ & $(0.0164)$ & $(0.0137)$ & $(0.0141)$ & $(0.384)$ & $(0.402)$ & $(0.458)$ & $(0.483)$ \\
\hline Observations & 4,453 & 4,453 & 4,453 & 4,453 & 1,996 & 1,996 & 2,376 & 2,376 \\
\hline
\end{tabular}

Standard errors in parentheses. ${ }^{*} \mathrm{p}<0.10,{ }^{* *} \mathrm{p}<0.05,{ }^{* * *} \mathrm{p}<0.01$. HRS respondents with $75+\%$ of job tenure linked to $\mathrm{O}^{*} \mathrm{Net}$ job characteristics. Regressions also control for HRS birth cohort, year of birth indicators, child health, and missing race/ethnicity. 
Table 6: Effects of Exposure to Job Characteristics, Disability and Retirement Outcomes: Women

\begin{tabular}{|c|c|c|c|c|c|c|c|c|}
\hline Total N-R Cog Analytical & \multicolumn{2}{|c|}{ Ever Apply DI } & \multicolumn{2}{|c|}{ Ever Get DI } & \multicolumn{2}{|c|}{ Age SS Claiming } & \multicolumn{2}{|c|}{ Age Retired } \\
\hline Total NR Cog Interperson & $-2.34 \mathrm{e}-05$ & & 0.000287 & & 0.00141 & & -0.00786 & \\
\hline \multirow[t]{2}{*}{ Total Routine Cognitive } & 0.000271 & & $-3.28 \mathrm{e}-05$ & & 0.00915 & & 0.000253 & \\
\hline & $(0.000347)$ & & $(0.000302)$ & & $(0.00610)$ & & $(0.00783)$ & \\
\hline Total Routine Manual & 0.000211 & & $-7.84 \mathrm{e}-05$ & & -0.00475 & & -0.00683 & \\
\hline Total NR Manual & $(0.000373)$ & & $(0.000325)$ & & $(0.00666)$ & & $(0.00847)$ & \\
\hline \multirow[t]{2}{*}{ Mean NR Cog Analytical } & & $-0.0355^{* * *}$ & & $-0.0345^{* * *}$ & & 0.388 & & 0.00351 \\
\hline & & $(0.0124)$ & & $(0.0108)$ & & $(0.248)$ & & $(0.318)$ \\
\hline \multirow[t]{2}{*}{ Mean NR Cog Interpersonal } & & 0.0132 & & $0.0228^{* *}$ & & -0.115 & & $-0.607^{* *}$ \\
\hline & & $(0.0103)$ & & $(0.00895)$ & & $(0.210)$ & & $(0.268)$ \\
\hline \multirow[t]{2}{*}{ Mean NR Manual } & & 0.0174 & & $0.0255^{* *}$ & & -0.177 & & -0.272 \\
\hline & & $(0.0123)$ & & $(0.0107)$ & & $(0.243)$ & & $(0.307)$ \\
\hline \multirow[t]{2}{*}{ Black } & $0.0820^{* * *}$ & $0.0665^{* * *}$ & $0.0442^{* * *}$ & $0.0306^{* *}$ & $-1.211^{* * *}$ & $-0.948^{* * *}$ & $-1.106^{* * *}$ & $-0.906^{* *}$ \\
\hline & $(0.0158)$ & $(0.0159)$ & $(0.0138)$ & $(0.0139)$ & $(0.321)$ & $(0.322)$ & $(0.402)$ & $(0.406)$ \\
\hline \multirow[t]{2}{*}{ Hispanic } & -0.0236 & $-0.0346^{*}$ & $-0.0583^{* * *}$ & $-0.0683^{* * *}$ & 0.689 & $0.851^{*}$ & -0.00648 & 0.149 \\
\hline & $(0.0207)$ & $(0.0207)$ & $(0.0180)$ & $(0.0180)$ & $(0.442)$ & $(0.441)$ & $(0.603)$ & $(0.604)$ \\
\hline \multirow[t]{2}{*}{ High School Grad } & $-0.0499^{* * *}$ & $-0.0406^{* *}$ & $-0.0530^{* * *}$ & $-0.0449^{* * *}$ & 0.252 & 0.0490 & -0.120 & -0.315 \\
\hline & $(0.0167)$ & $(0.0167)$ & $(0.0146)$ & $(0.0146)$ & $(0.307)$ & $(0.307)$ & $(0.402)$ & $(0.404)$ \\
\hline \multirow[t]{2}{*}{ College +} & $-0.0967^{* * *}$ & $-0.0630^{* * *}$ & $-0.0853^{* * *}$ & $-0.0559^{* * *}$ & $1.059^{* * *}$ & 0.377 & $1.269^{* * *}$ & 0.549 \\
\hline & $(0.0183)$ & $(0.0187)$ & $(0.0160)$ & $(0.0163)$ & $(0.353)$ & $(0.359)$ & $(0.449)$ & $(0.459)$ \\
\hline Observations & 3,457 & 3,457 & 3,457 & 3,457 & 1,769 & 1,769 & 1,985 & 1,985 \\
\hline
\end{tabular}

Standard errors in parentheses. ${ }^{*} \mathrm{p}<0.10,{ }^{* *} \mathrm{p}<0.05,{ }^{* * *} \mathrm{p}<0.01$. HRS respondents with $75+\%$ of job tenure linked to $\mathrm{O}^{*} \mathrm{Net}$ job characteristics. Regressions also control for HRS birth cohort, year of birth indicators, child health, and missing race/ethnicity. 
Table 7: Cumulative Exposure to Job Characteristics and Work-Limiting Health Conditions Later

\begin{tabular}{|c|c|c|c|c|c|c|c|c|}
\hline & \multicolumn{2}{|c|}{ Age 62} & \multicolumn{2}{|c|}{ Age 65} & \multicolumn{2}{|c|}{ Age 70} & \multicolumn{2}{|c|}{ Age 75} \\
\hline & Self-Rep & Predicted & Self-Rep & Predicted & Self-Rep & Predicted & Self-Rep & Predicted \\
\hline \multirow[t]{2}{*}{ Total N-R Cog Analytical } & $0.00158^{* * *}$ & $0.00108^{* * *}$ & $0.00152^{* * *}$ & $0.00102^{* * *}$ & $0.00155^{* * *}$ & $0.00104^{* * *}$ & $0.00152^{* * *}$ & $0.00102^{* * *}$ \\
\hline & $(0.000369)$ & $(0.000340)$ & $(0.000372)$ & $(0.000340)$ & $(0.000375)$ & $(0.000340)$ & $(0.000372)$ & $(0.000340)$ \\
\hline \multirow[t]{2}{*}{ Total NR Cog Interperson } & $-0.000528^{*}$ & $-0.000551^{* *}$ & $-0.000501^{*}$ & $-0.000554^{* *}$ & -0.000480 & $-0.000502^{*}$ & $-0.000501^{*}$ & $-0.000554^{* *}$ \\
\hline & $(0.000294)$ & $(0.000278)$ & $(0.000296)$ & $(0.000277)$ & $(0.000298)$ & $(0.000278)$ & $(0.000296)$ & $(0.000277)$ \\
\hline \multirow{2}{*}{ Total Routine Cognitive } & -0.000300 & $-4.13 e-05$ & -0.000297 & $-1.79 \mathrm{e}-05$ & -0.000171 & $-3.62 \mathrm{e}-05$ & -0.000297 & $-1.79 \mathrm{e}-05$ \\
\hline & $(0.000287)$ & $(0.000253)$ & $(0.000289)$ & $(0.000253)$ & $(0.000291)$ & $(0.000253)$ & $(0.000289)$ & $(0.000253)$ \\
\hline \multirow[t]{2}{*}{ Total Routine Manual } & 0.000565 & $-8.48 \mathrm{e}-05$ & 0.000542 & $-7.63 e-05$ & 0.000565 & $-8.33 e-05$ & 0.000542 & $-7.63 e-05$ \\
\hline & $(0.000445)$ & $(0.000391)$ & $(0.000447)$ & $(0.000391)$ & $(0.000451)$ & $(0.000392)$ & $(0.000447)$ & $(0.000391)$ \\
\hline \multirow[t]{2}{*}{ Total NR Manual } & $0.00112^{* * *}$ & $0.00110^{* * *}$ & $0.00118^{* * *}$ & $0.00108^{* * *}$ & $0.00102^{* *}$ & $0.00109^{* * *}$ & $0.00118^{* * *}$ & $0.00108^{* * *}$ \\
\hline & $(0.000392)$ & $(0.000354)$ & $(0.000395)$ & $(0.000353)$ & $(0.000397)$ & $(0.000354)$ & $(0.000395)$ & $(0.000353)$ \\
\hline \multirow[t]{2}{*}{ Black } & $0.0356^{* * *}$ & $0.0659^{* * *}$ & $0.0377^{* * *}$ & $0.0651^{* * *}$ & $0.0354^{* * *}$ & $0.0671^{* * *}$ & $0.0377^{* * *}$ & $0.0651^{* * *}$ \\
\hline & $(0.0125)$ & $(0.0122)$ & $(0.0126)$ & $(0.0122)$ & $(0.0126)$ & $(0.0122)$ & $(0.0126)$ & $(0.0122)$ \\
\hline \multirow[t]{2}{*}{ Hispanic } & $-0.0682^{* * *}$ & $-0.0277^{*}$ & $-0.0676^{* * *}$ & -0.0259 & $-0.0700^{* * *}$ & $-0.0286^{*}$ & $-0.0676^{* * *}$ & -0.0259 \\
\hline & $(0.0167)$ & $(0.0163)$ & $(0.0168)$ & $(0.0164)$ & $(0.0168)$ & $(0.0164)$ & $(0.0168)$ & $(0.0164)$ \\
\hline \multirow[t]{2}{*}{ High School Grad } & $-0.0771^{* * *}$ & $-0.0907^{* * *}$ & $-0.0778^{* * *}$ & $-0.0911^{* * *}$ & $-0.0851^{* * *}$ & $-0.0916^{* * *}$ & $-0.0778^{* * *}$ & $-0.0911^{* * *}$ \\
\hline & $(0.0145)$ & $(0.0137)$ & $(0.0146)$ & $(0.0137)$ & $(0.0147)$ & $(0.0138)$ & $(0.0146)$ & $(0.0137)$ \\
\hline \multirow[t]{2}{*}{ College +} & $-0.122^{* * *}$ & $-0.153^{* * *}$ & $-0.121^{* * *}$ & $-0.153^{* * *}$ & $-0.132^{* * *}$ & $-0.153^{* * *}$ & $-0.121^{* * *}$ & $-0.153^{* * *}$ \\
\hline & & & & & & & & $(0.0152)$ \\
\hline V. Good & $(0.0117)$ & $(0.0110)$ & $(0.0117)$ & $(0.0110)$ & $(0.0118)$ & $(0.0110)$ & $(0.0117)$ & $(0.0110)$ \\
\hline \multirow[t]{2}{*}{ Child Health Good } & $0.108^{* * *}$ & $0.0944^{* * *}$ & $0.112^{* * *}$ & $0.0962^{* * *}$ & $0.105^{* * *}$ & $0.0946^{* * *}$ & $0.112^{* * *}$ & $0.0962^{* * *}$ \\
\hline & $(0.0143)$ & $(0.0138)$ & $(0.0144)$ & $(0.0138)$ & $(0.0145)$ & $(0.0138)$ & $(0.0144)$ & $(0.0138)$ \\
\hline \multirow[t]{2}{*}{ Child Health Fair } & $0.184^{* * *}$ & $0.149^{* * *}$ & $0.192^{* * *}$ & $0.149^{* * *}$ & $0.181^{* * *}$ & $0.146^{* * *}$ & $0.192^{* * * *}$ & $0.149^{* * *}$ \\
\hline & $(0.0233)$ & $(0.0223)$ & $(0.0235)$ & $(0.0223)$ & $(0.0234)$ & $(0.0222)$ & $(0.0235)$ & $(0.0223)$ \\
\hline \multirow[t]{2}{*}{ Child Health Poor } & $0.202^{* * *}$ & $0.181^{* * *}$ & $0.201^{* * *}$ & $0.182^{* * *}$ & $0.201^{* * *}$ & $0.180^{* * *}$ & $0.201^{* * *}$ & $0.182^{* * *}$ \\
\hline & $(0.0394)$ & $(0.0386)$ & $(0.0398)$ & $(0.0385)$ & $(0.0394)$ & $(0.0387)$ & $(0.0398)$ & $(0.0385)$ \\
\hline \multirow[t]{2}{*}{ Female } & 0.00856 & $0.0404^{* * *}$ & 0.00712 & $0.0402^{* * *}$ & 0.00749 & $0.0407^{* * *}$ & 0.00712 & $0.0402^{* * *}$ \\
\hline & $(0.0108)$ & $(0.0105)$ & $(0.0108)$ & $(0.0105)$ & $(0.0109)$ & $(0.0105)$ & $(0.0108)$ & $(0.0105)$ \\
\hline Obs & 7,220 & 3,555 & 7,153 & 3,546 & 7,069 & 3,562 & 7,153 & 3,546 \\
\hline
\end{tabular}

Standard errors in parentheses. ${ }^{*} \mathrm{p}<0.10,{ }^{* *} \mathrm{p}<0.05,{ }^{* * *} \mathrm{p}<0.01$. HRS respondents with $75+\%$ of job tenure linked to $\mathrm{O}^{*} \mathrm{Net}$ job characteristics. Regressions also control for HRS birth cohort, year of birth indicators, and missing race/ethnicity. Predicted health limits work measure is prediction from a probit regression using self-reported history of chronic conditions and activities of daily living limitations based on Bound (1991). 
Table 8: Average Exposure to Job Characteristics and Work-Limiting Health Conditions Later in Life

\begin{tabular}{|c|c|c|c|c|c|c|c|c|}
\hline & \multicolumn{2}{|c|}{ Age 62} & \multicolumn{2}{|c|}{ Age 65} & \multicolumn{2}{|c|}{ Age 70} & \multicolumn{2}{|c|}{ Age 75} \\
\hline & Self-Rep & Predicted & Self-Rep & Predicted & Self-Rep & Predicted & Self-Rep & Predicted \\
\hline \multirow[t]{2}{*}{ Mean NR Cog Analytical } & -0.000598 & 0.000887 & -0.00116 & -0.000898 & -0.00216 & 0.000147 & -0.00116 & -0.000898 \\
\hline & $(0.0116)$ & $(0.0114)$ & $(0.0117)$ & $(0.0114)$ & $(0.0117)$ & $(0.0114)$ & $(0.0117)$ & $(0.0114)$ \\
\hline \multirow[t]{2}{*}{ Mean NR Cog Interpersonal } & 0.000172 & -0.00154 & 0.000202 & -0.00162 & 0.00130 & -0.000264 & 0.000202 & -0.00162 \\
\hline & $(0.00898)$ & $(0.00919)$ & $(0.00902)$ & $(0.00918)$ & $(0.00908)$ & $(0.00920)$ & $(0.00902)$ & $(0.00918)$ \\
\hline \multirow{2}{*}{ Mean Routine Cogntive } & $-0.0158^{*}$ & -0.00578 & $-0.0153^{*}$ & -0.00528 & -0.0126 & -0.00575 & $-0.0153^{*}$ & -0.00528 \\
\hline & $(0.00841)$ & $(0.00797)$ & $(0.00845)$ & $(0.00796)$ & $(0.00851)$ & $(0.00798)$ & $(0.00845)$ & $(0.00796)$ \\
\hline \multirow[t]{2}{*}{ Mean Routine Manual } & $0.0230^{*}$ & 0.00611 & 0.0219 & 0.00622 & $0.0237^{*}$ & 0.00620 & 0.0219 & 0.00622 \\
\hline & $(0.0134)$ & $(0.0126)$ & $(0.0135)$ & $(0.0126)$ & $(0.0136)$ & $(0.0127)$ & $(0.0135)$ & $(0.0126)$ \\
\hline \multirow[t]{2}{*}{ Mean NR Manual } & $0.0262^{* *}$ & $0.0321^{* * *}$ & $0.0277^{* *}$ & $0.0314^{* * *}$ & $0.0229^{*}$ & $0.0318^{* * *}$ & $0.0277^{* *}$ & $0.0314^{* * *}$ \\
\hline & $(0.0123)$ & $(0.0119)$ & $(0.0124)$ & $(0.0119)$ & $(0.0124)$ & $(0.0119)$ & $(0.0124)$ & $(0.0119)$ \\
\hline \multirow[t]{2}{*}{ Black } & $0.0261^{* *}$ & $0.0580^{* * *}$ & $0.0284^{* *}$ & $0.0571^{* * *}$ & $0.0258^{* *}$ & $0.0592^{* * *}$ & $0.0284^{* *}$ & $0.0571^{* * *}$ \\
\hline & $(0.0126)$ & $(0.0122)$ & $(0.0127)$ & $(0.0122)$ & $(0.0127)$ & $(0.0122)$ & $(0.0127)$ & $(0.0122)$ \\
\hline \multirow[t]{2}{*}{ Hispanic } & $-0.0745^{* * *}$ & $-0.0305^{*}$ & $-0.0740^{* * *}$ & $-0.0290^{*}$ & $-0.0761^{* * *}$ & $-0.0314^{*}$ & $-0.0740^{* * *}$ & $-0.0290^{*}$ \\
\hline & $(0.0167)$ & $(0.0164)$ & $(0.0169)$ & $(0.0164)$ & $(0.0168)$ & $(0.0164)$ & $(0.0169)$ & $(0.0164)$ \\
\hline \multirow{2}{*}{ High School Grad } & $-0.0687^{* * *}$ & $-0.0838^{* * *}$ & $-0.0699^{* * *}$ & $-0.0841^{* * *}$ & $-0.0764^{* * *}$ & $-0.0847^{* * *}$ & $-0.0699 * * *$ & $-0.0841^{* * *}$ \\
\hline & $(0.0146)$ & $(0.0139)$ & $(0.0147)$ & $(0.0138)$ & $(0.0148)$ & $(0.0139)$ & $(0.0147)$ & $(0.0138)$ \\
\hline \multirow[t]{2}{*}{ College +} & $-0.0966^{* * *}$ & $-0.134^{* * *}$ & $-0.0966^{* * *}$ & $-0.134^{* * * *}$ & $-0.106^{* * * *}$ & $-0.134^{* * *}$ & $-0.0966^{* * *}$ & $-0.134^{* * *}$ \\
\hline & $(0.0162)$ & $(0.0156)$ & $(0.0163)$ & $(0.0156)$ & $(0.0163)$ & $(0.0156)$ & $(0.0163)$ & $(0.0156)$ \\
\hline \multirow[t]{2}{*}{ Child Health V. Good } & $0.0415^{* * *}$ & $0.0491^{* * *}$ & $0.0414^{* * *}$ & $0.0494^{* * *}$ & $0.0405^{* * *}$ & $0.0491^{* * *}$ & $0.0414^{* * *}$ & $0.0494^{* * *}$ \\
\hline & $(0.0117)$ & $(0.0110)$ & $(0.0117)$ & $(0.0110)$ & $(0.0118)$ & $(0.0110)$ & $(0.0117)$ & $(0.0110)$ \\
\hline \multirow[t]{2}{*}{ Child Health Good } & $0.106^{* * *}$ & $0.0926^{* * *}$ & $0.109^{* * *}$ & $0.0944^{* * *}$ & $0.102^{* * *}$ & $0.0927^{* * *}$ & $0.109^{* * *}$ & $0.0944^{* * *}$ \\
\hline & $(0.0143)$ & $(0.0138)$ & $(0.0144)$ & $(0.0138)$ & $(0.0145)$ & $(0.0138)$ & $(0.0144)$ & $(0.0138)$ \\
\hline \multirow[t]{2}{*}{ Child Health Fair } & $0.185^{* * *}$ & $0.151^{* * *}$ & $0.194^{* * *}$ & $0.150^{* * *}$ & $0.183^{* * *}$ & $0.148^{* * *}$ & $0.194^{* * *}$ & $0.150^{* * *}$ \\
\hline & $(0.0233)$ & $(0.0222)$ & $(0.0235)$ & $(0.0223)$ & $(0.0234)$ & $(0.0222)$ & $(0.0235)$ & $(0.0223)$ \\
\hline \multirow[t]{2}{*}{ Child Health Poor } & $0.196^{* * *}$ & $0.181^{* * *}$ & $0.194^{* * *}$ & $0.182^{* * *}$ & $0.194^{* * *}$ & $0.180^{* * *}$ & $0.194^{* * *}$ & $0.182^{* * *}$ \\
\hline & $(0.0395)$ & $(0.0386)$ & $(0.0398)$ & $(0.0385)$ & $(0.0394)$ & $(0.0387)$ & $(0.0398)$ & $(0.0385)$ \\
\hline \multirow[t]{2}{*}{ Female } & 0.00942 & $0.0438^{* * *}$ & 0.00772 & $0.0433^{* * *}$ & 0.00866 & $0.0441^{* * *}$ & 0.00772 & $0.0433^{* * *}$ \\
\hline & $(0.0111)$ & $(0.0107)$ & $(0.0112)$ & $(0.0107)$ & $(0.0112)$ & $(0.0107)$ & $(0.0112)$ & $(0.0107)$ \\
\hline Observations & 7,220 & 3,555 & 7,153 & 3,546 & 7,069 & 3,562 & 7,153 & 3,546 \\
\hline
\end{tabular}


Table A1: Effects of Job Characteristics on Disability and Retirement Outcomes: Pooled Sample Including Respondents with Missing Job Characteristics

\begin{tabular}{|c|c|c|c|c|c|c|c|c|}
\hline & \multicolumn{2}{|c|}{ Ever Apply DI } & \multicolumn{2}{|c|}{ Ever Get DI } & \multicolumn{2}{|c|}{ Age SS Claiming } & \multicolumn{2}{|c|}{ Age Retired } \\
\hline \multirow[t]{2}{*}{ Total NR Cog./An. } & $0.000597^{* *}$ & & 0.000335 & & $-0.0104^{* *}$ & & $-0.0336^{* * *}$ & \\
\hline & $(0.000248)$ & & $(0.000215)$ & & $(0.00518)$ & & $(0.00620)$ & \\
\hline \multirow{2}{*}{ Total NR Cog./Int. } & -0.000137 & & 0.000101 & & 0.00361 & & 0.00242 & \\
\hline & $(0.000202)$ & & $(0.000175)$ & & $(0.00427)$ & & $(0.00513)$ & \\
\hline \multirow[t]{2}{*}{ Total R Cog. } & $9.45 e-06$ & & $1.02 \mathrm{e}-05$ & & 0.00659 & & -0.00826 & \\
\hline & $(0.000211)$ & & $(0.000183)$ & & $(0.00443)$ & & $(0.00529)$ & \\
\hline \multirow[t]{2}{*}{ Total R Man. } & 0.000258 & & 0.000203 & & -0.00146 & & -0.00330 & \\
\hline & $(0.000292)$ & & $(0.000253)$ & & $(0.00589)$ & & $(0.00716)$ & \\
\hline \multirow[t]{2}{*}{ Total NR Man./Phys. } & $0.000885^{* * * *}$ & & $0.000786^{* * *}$ & & -0.00702 & & $-0.0148^{* *}$ & \\
\hline & $(0.000252)$ & & $(0.000219)$ & & $(0.00517)$ & & $(0.00627)$ & \\
\hline \multirow[t]{2}{*}{ Mean NR Cog./An. } & & $-0.0177^{* *}$ & & $-0.0163^{* *}$ & & $0.484^{* * *}$ & & 0.0638 \\
\hline & & $(0.00787)$ & & $(0.00683)$ & & $(0.182)$ & & $(0.217)$ \\
\hline \multirow[t]{2}{*}{ Mean NR Cog./Int. } & & 0.00673 & & $0.0127^{* *}$ & & -0.155 & & $-0.353^{* *}$ \\
\hline & & $(0.00628)$ & & $(0.00545)$ & & $(0.148)$ & & $(0.178)$ \\
\hline \multirow{2}{*}{ Mean R Cog. } & & -0.00419 & & -0.00269 & & $0.297^{* *}$ & & -0.115 \\
\hline & & $(0.00625)$ & & $(0.00542)$ & & $(0.144)$ & & $(0.172)$ \\
\hline \multirow[t]{2}{*}{ Mean R Man. } & & $0.0165^{*}$ & & 0.0125 & & -0.121 & & -0.319 \\
\hline & & $(0.00900)$ & & $(0.00781)$ & & $(0.195)$ & & $(0.241)$ \\
\hline \multirow[t]{2}{*}{ Mean NR Man./Phys. } & & $0.0227^{* * *}$ & & $0.0200^{* * *}$ & & -0.0927 & & -0.0817 \\
\hline & & $(0.00793)$ & & $(0.00688)$ & & $(0.176)$ & & $(0.215)$ \\
\hline Observations & 10,118 & 10,118 & 10,118 & 10,118 & 4,598 & 4,598 & 5,395 & 5,395 \\
\hline
\end{tabular}

Standard errors in parentheses. ${ }^{*} \mathrm{p}<0.10,{ }^{* *} \mathrm{p}<0.05,{ }^{* * *} \mathrm{p}<0.01$. HRS respondents with $75+\%$ of job tenure linked to $\mathrm{O}^{*} \mathrm{Net}$ job characteristics. Regressions also control for HRS birth cohort, year of birth indicators, child health, missing race/ethnicity, indicators for jobs with missing $\mathrm{O}^{*}$ Net reports, and Table 4 controls. 
Table A2: Effects of Job Characteristics on Disability and Retirement Outcomes: Pooled Sample Including Respondents with Missing Job Characteristics

\begin{tabular}{|c|c|c|c|c|c|c|c|c|}
\hline & \multicolumn{2}{|c|}{ Ever Apply DI } & \multicolumn{2}{|c|}{ Ever Get DI } & \multicolumn{2}{|c|}{ Age SS Claiming } & \multicolumn{2}{|c|}{ Age Retired } \\
\hline \multirow[t]{2}{*}{ Total NR Cog./An. } & $0.000836^{* * *}$ & & $0.000501^{* * *}$ & & $-0.0167^{* * *}$ & & $-0.0518^{* * *}$ & \\
\hline & $(0.000210)$ & & $(0.000181)$ & & $(0.00420)$ & & $(0.00519)$ & \\
\hline \multirow[t]{2}{*}{ Total NR Cog./Int. } & -0.000232 & & $-1.59 \mathrm{e}-05$ & & $0.00756^{* *}$ & & $0.0132^{* * *}$ & \\
\hline & $(0.000174)$ & & $(0.000150)$ & & $(0.00352)$ & & $(0.00435)$ & \\
\hline \multirow[t]{2}{*}{ Total R Cog. } & $7.69 \mathrm{e}-06$ & & $7.95 \mathrm{e}-05$ & & 0.00363 & & $-0.00972^{* *}$ & \\
\hline & $(0.000183)$ & & $(0.000158)$ & & $(0.00369)$ & & $(0.00451)$ & \\
\hline \multirow[t]{2}{*}{ Total R Man. } & 0.000190 & & 0.000153 & & 0.00248 & & 0.00229 & \\
\hline & $(0.000254)$ & & $(0.000219)$ & & $(0.00492)$ & & $(0.00617)$ & \\
\hline \multirow[t]{2}{*}{ Total R Man./Phys. } & $0.00108^{* * *}$ & & $0.000867^{* * *}$ & & $-0.0109^{* *}$ & & $-0.0256^{* * *}$ & \\
\hline & $(0.000220)$ & & $(0.000190)$ & & $(0.00433)$ & & $(0.00541)$ & \\
\hline \multirow[t]{2}{*}{ Mean NR Cog./An. } & & $-0.0263^{* * *}$ & & $-0.0174^{* * *}$ & & $0.558^{* * *}$ & & 0.205 \\
\hline & & $(0.00542)$ & & $(0.00467)$ & & $(0.115)$ & & $(0.144)$ \\
\hline \multirow[t]{2}{*}{ Mean NR Cog./Int. } & & $0.0106^{* *}$ & & $0.0119^{* * *}$ & & -0.0925 & & -0.128 \\
\hline & & $(0.00439)$ & & $(0.00379)$ & & $(0.0951)$ & & $(0.119)$ \\
\hline \multirow[t]{2}{*}{ Mean R Cog. (imp.) } & & -0.00614 & & 0.00183 & & $0.157^{*}$ & & -0.0909 \\
\hline & & $(0.00439)$ & & $(0.00379)$ & & $(0.0937)$ & & $(0.116)$ \\
\hline \multirow[t]{2}{*}{ Mean R Man. (imp.) } & & $0.0176^{* * *}$ & & $0.0151^{* * *}$ & & -0.198 & & -0.174 \\
\hline & & $(0.00636)$ & & $(0.00549)$ & & $(0.130)$ & & $(0.166)$ \\
\hline \multirow[t]{2}{*}{ Mean NR Man./Phys. } & & $0.0188^{* * *}$ & & $0.0156^{* * *}$ & & 0.00764 & & -0.0143 \\
\hline & & $(0.00566)$ & & $(0.00489)$ & & $(0.117)$ & & $(0.148)$ \\
\hline Observations & 21,431 & 21,430 & 21,431 & 21,430 & 10,805 & 10,804 & 12,329 & 12,329 \\
\hline
\end{tabular}

Standard errors in parentheses. ${ }^{*} \mathrm{p}<0.10,{ }^{* *} \mathrm{p}<0.05,{ }^{* * *} \mathrm{p}<0.01$. HRS respondents with any job tenure linked to $\mathrm{O}^{*} \mathrm{Net}$ job characteristics. Regressions also control for HRS birth cohort, year of birth indicators, child health, missing race/ethnicity, indicators for jobs with missing $\mathrm{O}^{*}$ Net reports, and Table 4 controls. 
Table A3: Effects of Job Characteristics on Disability and Retirement Outcomes: Pooled Sample with Alternative Job Characteristic Measures

\begin{tabular}{|c|c|c|c|c|c|c|c|c|}
\hline & \multicolumn{2}{|c|}{ Ever Apply DI } & \multicolumn{2}{|c|}{ Ever Get DI } & \multicolumn{2}{|c|}{ Age SS Claiming } & \multicolumn{2}{|c|}{ Age Retired } \\
\hline \multirow[t]{2}{*}{ Total Phys. Demands } & 0.000152 & & $0.000220^{*}$ & & $0.00691^{* *}$ & & $0.0150^{* * *}$ & \\
\hline & $(0.000146)$ & & $(0.000127)$ & & $(0.00293)$ & & $(0.00354)$ & \\
\hline \multirow[t]{2}{*}{ Total Activity Level } & -0.000105 & & $-1.02 \mathrm{e}-05$ & & 0.00133 & & 0.000793 & \\
\hline & $(0.000171)$ & & $(0.000149)$ & & $(0.00336)$ & & $(0.00404)$ & \\
\hline \multirow[t]{2}{*}{ Total Status Recog. } & $-0.000561^{* * *}$ & & $-0.000340^{* *}$ & & $0.0224^{* * *}$ & & $0.0192^{* * *}$ & \\
\hline & $(0.000162)$ & & $(0.000141)$ & & $(0.00331)$ & & $(0.00400)$ & \\
\hline \multirow[t]{2}{*}{ Total Exp. To Conflict } & $0.000842^{* * *}$ & & $0.000716^{* * * *}$ & & $-0.0190^{* * *}$ & & $-0.0334^{* * *}$ & \\
\hline & $(0.000222)$ & & $(0.000193)$ & & $(0.00462)$ & & $(0.00537)$ & \\
\hline \multirow[t]{2}{*}{ Total Self-Direction } & $1.26 \mathrm{e}-05$ & & $-3.52 e-05$ & & 0.00235 & & $-0.0112^{* *}$ & \\
\hline & $(0.000193)$ & & $(0.000168)$ & & $(0.00396)$ & & $(0.00468)$ & \\
\hline \multirow[t]{2}{*}{ Total Care on Work } & $-0.00123^{* * *}$ & & $-0.00101^{* * *}$ & & $0.0151^{* * *}$ & & $0.0426^{* * *}$ & \\
\hline & $(0.000260)$ & & $(0.000226)$ & & $(0.00534)$ & & $(0.00632)$ & \\
\hline \multirow[t]{2}{*}{ Mean Phys. Demands } & & $0.0258^{* * *}$ & & $0.0218^{* * *}$ & & $-0.229^{* *}$ & & -0.119 \\
\hline & & $(0.00496)$ & & $(0.00430)$ & & $(0.110)$ & & $(0.133)$ \\
\hline \multirow[t]{2}{*}{ Mean Activity Level } & & 0.00182 & & 0.00324 & & -0.0803 & & -0.191 \\
\hline & & $(0.00572)$ & & $(0.00496)$ & & $(0.122)$ & & $(0.148)$ \\
\hline \multirow[t]{2}{*}{ Mean Status Recog. } & & $-0.00989^{*}$ & & -0.00331 & & $0.467^{* * *}$ & & 0.167 \\
\hline & & $(0.00529)$ & & $(0.00459)$ & & $(0.120)$ & & $(0.145)$ \\
\hline \multirow[t]{2}{*}{ Mean Exp. To Conflict } & & $0.0148^{* *}$ & & $0.0145^{* *}$ & & $-0.418^{* * * *}$ & & $-0.665^{* * *}$ \\
\hline & & $(0.00686)$ & & $(0.00595)$ & & $(0.158)$ & & $(0.185)$ \\
\hline \multirow[t]{2}{*}{ Mean Self-Direction } & & -0.00776 & & -0.00510 & & 0.152 & & $-0.273^{*}$ \\
\hline & & $(0.00614)$ & & $(0.00533)$ & & $(0.139)$ & & $(0.165)$ \\
\hline \multirow[t]{2}{*}{ Mean Care on Work } & & $-0.0185^{* *}$ & & $-0.0184^{* * *}$ & & -0.0116 & & $0.566^{* * *}$ \\
\hline & & $(0.00786)$ & & $(0.00682)$ & & $(0.179)$ & & $(0.215)$ \\
\hline Observations & 10,118 & 10,118 & 10,118 & 10,118 & 4,598 & 4,598 & 5,395 & 5,395 \\
\hline
\end{tabular}

Standard errors in parentheses. ${ }^{*} \mathrm{p}<0.10,{ }^{* *} \mathrm{p}<0.05,{ }^{* * *} \mathrm{p}<0.01$. HRS respondents with any job tenure linked to $\mathrm{O}^{*} \mathrm{Net}$ job characteristics. Regressions also control for HRS birth cohort, year of birth indicators, child health, and missing race/ethnicity and Table 4 controls. 
Table A4: Effects of Cumulative and Mean Exposure to Job Characteristics and Work-Limiting Health Conditions Later in Life

\begin{tabular}{|c|c|c|c|c|c|c|c|c|}
\hline & \multicolumn{2}{|c|}{ Age 62} & \multicolumn{2}{|c|}{ Age 65} & \multicolumn{2}{|c|}{ Age 70} & \multicolumn{2}{|c|}{ Age 75} \\
\hline & Self-Rep & Predicted & Self-Rep & Predicted & Self-Rep & Predicted & Self-Rep & Predicted \\
\hline \multicolumn{9}{|l|}{ Cumulative } \\
\hline \multirow[t]{2}{*}{ Total NR Cog./ An. } & $0.00166^{* * *}$ & $0.00101^{* * *}$ & $0.00168^{* * * *}$ & $0.000999^{* * *}$ & $0.00164^{* * *}$ & $0.00101^{* * *}$ & $0.00168^{* * *}$ & $0.000999^{* * *}$ \\
\hline & $(0.000285)$ & $(0.000259)$ & $(0.000287)$ & $(0.000260)$ & $(0.000291)$ & $(0.000259)$ & $(0.000287)$ & $(0.000260)$ \\
\hline \multirow[t]{2}{*}{ Total NR Cog./Int. } & $-0.000478^{* *}$ & $-0.000420^{*}$ & $-0.000502^{* *}$ & $-0.000426^{* *}$ & $-0.000442^{*}$ & $-0.000394^{*}$ & $-0.000502^{* *}$ & $-0.000426^{* *}$ \\
\hline & $(0.000233)$ & $(0.000217)$ & $(0.000234)$ & $(0.000217)$ & $(0.000237)$ & $(0.000217)$ & $(0.000234)$ & $(0.000217)$ \\
\hline \multirow[t]{2}{*}{ Total R Cog. } & $-6.57 e-05$ & $3.01 \mathrm{e}-05$ & $-4.93 e-05$ & $5.45 \mathrm{e}-05$ & $5.28 \mathrm{e}-05$ & $3.99 \mathrm{e}-05$ & $-4.93 e-05$ & $5.45 \mathrm{e}-05$ \\
\hline & $(0.000248)$ & $(0.000219)$ & $(0.000249)$ & $(0.000219)$ & $(0.000252)$ & $(0.000219)$ & $(0.000249)$ & $(0.000219)$ \\
\hline \multirow[t]{2}{*}{ Total R Man. } & 0.000249 & $-3.59 e-05$ & 0.000200 & $-3.62 e-05$ & 0.000266 & $-4.21 \mathrm{e}-05$ & 0.000200 & $-3.62 e-05$ \\
\hline & $(0.000344)$ & $(0.000306)$ & $(0.000346)$ & $(0.000306)$ & $(0.000350)$ & $(0.000306)$ & $(0.000346)$ & $(0.000306)$ \\
\hline \multirow[t]{2}{*}{ Total R Man./Phys. } & $0.00171^{* * *}$ & $0.00117^{* * *}$ & $0.00181^{* * *}$ & $0.00117^{* * *}$ & $0.00162^{* * *}$ & $0.00118^{* * *}$ & $0.00181^{* * * *}$ & $0.00117^{* * *}$ \\
\hline & $(0.000304)$ & $(0.000274)$ & $(0.000306)$ & $(0.000275)$ & $(0.000309)$ & $(0.000275)$ & $(0.000306)$ & $(0.000275)$ \\
\hline Observations & 19,153 & 10,036 & 18,986 & 10,003 & 18,609 & 10,055 & 18,986 & 10,003 \\
\hline \multicolumn{9}{|l|}{ Average } \\
\hline \multirow[t]{2}{*}{ Mean NR Cog./An. } & $-0.0247^{* * *}$ & $-0.0254^{* * *}$ & $-0.0240^{* * *}$ & $-0.0260^{* * *}$ & $-0.0266^{* * *}$ & $-0.0254^{* * *}$ & $-0.0240^{* * *}$ & $-0.0260^{* * *}$ \\
\hline & $(0.00728)$ & $(0.00669)$ & $(0.00732)$ & $(0.00670)$ & $(0.00740)$ & $(0.00669)$ & $(0.00732)$ & $(0.00670)$ \\
\hline \multirow[t]{2}{*}{ Mean NR Cog./Int. } & $0.0110^{*}$ & 0.00802 & $0.0104^{*}$ & 0.00808 & $0.0120^{* *}$ & 0.00856 & $0.0104^{*}$ & 0.00808 \\
\hline & $(0.00583)$ & $(0.00550)$ & $(0.00586)$ & $(0.00550)$ & $(0.00593)$ & $(0.00550)$ & $(0.00586)$ & $(0.00550)$ \\
\hline \multirow[t]{2}{*}{ Mean R Cog. } & -0.00946 & -0.00633 & -0.00861 & -0.00582 & -0.00744 & -0.00614 & -0.00861 & -0.00582 \\
\hline & $(0.00590)$ & $(0.00533)$ & $(0.00592)$ & $(0.00533)$ & $(0.00600)$ & $(0.00533)$ & $(0.00592)$ & $(0.00533)$ \\
\hline \multirow[t]{2}{*}{ Mean R Man. } & 0.00745 & 0.00193 & 0.00622 & 0.00166 & 0.00858 & 0.00158 & 0.00622 & 0.00166 \\
\hline & $(0.00855)$ & $(0.00768)$ & $(0.00859)$ & $(0.00769)$ & $(0.00869)$ & $(0.00768)$ & $(0.00859)$ & $(0.00769)$ \\
\hline \multirow[t]{2}{*}{ Mean R Man./Phys. } & $0.0390^{* * *}$ & $0.0274^{* * *}$ & $0.0409^{* * *}$ & $0.0273^{* * *}$ & $0.0359^{* * *}$ & $0.0282^{* * *}$ & $0.0409^{* * *}$ & $0.0273^{* * *}$ \\
\hline & $(0.00793)$ & $(0.00726)$ & $(0.00797)$ & $(0.00728)$ & $(0.00805)$ & $(0.00727)$ & $(0.00797)$ & $(0.00728)$ \\
\hline Observations & 19,152 & 10,035 & 18,985 & 10,002 & 18,608 & 10,054 & 18,985 & 10,002 \\
\hline
\end{tabular}

Standard errors in parentheses. ${ }^{*} \mathrm{p}<0.10,{ }^{* *} \mathrm{p}<0.05,{ }^{* * *} \mathrm{p}<0.01$. HRS respondents with $75+\%$ of job tenure

linked to $\mathrm{O}^{*} \mathrm{Net}$ job characteristics. Regressions also control for HRS birth cohort, year of birth indicators, Table 7 demographics, indicators for missing race/ethnicity and $\mathrm{O}^{*} \mathrm{Net}$ data. Predicted health limits work measure is prediction from a probit regression using self-reported history of chronic conditions and activities of daily living limitations based on Bound (1991). 


\section{RECENT WORKING PAPERS FROM THE CENTER FOR RETIREMENT RESEARCH AT BOSTON COLLEGE}

Who Is Internationally Diversified? Evidence from $296401(\mathrm{k})$ Plans

Geert Bekaert, Kenton Hoyem, Wei-Yin Hu, and Enrichetta Ravina, November 2014

The Causes and Consequences of Financial Fraud Among Older Americans

Keith Jacks Gamble, Patricia Boyle, Lei Yu, and David Bennett, November 2014

New Evidence on the Risk of Requiring Long-Term Care

Leora Friedberg, Wenliang Hou, Wei Sun, Anthony Webb, and Zhenyu Li, November 2014

SSI at 62: Protecting the Vulnerable When Increasing Social Security's Early Entitlement Age

Norma B. Coe and April Yanyuan Wu, June 2014

Why Do SSI and SNAP Enrollments Rise in Good Economic Times and Bad?

Matthew S. Rutledge and April Yanyuan Wu, June 2014

The Impact of Mandatory Coverage on State and Local Budgets

Alicia H. Munnell, Jean-Pierre Aubry, and Anek Belbase, May 2014

Interest Rates and Economic Growth: Are They Related?

Barry P. Bosworth, May 2014

The Tradeoff Between Health and Wealth in Retirement Decisions

Kristine M. Brown, May 2014

The Effect of Increasing Earnings Dispersion on Social Security Payroll Tax Receipts Richard Kopcke, Zhenyu Li, and Anthony Webb, May 2014

What Impact Does Social Security Have on the Use of Public Assistance Programs Among the Elderly?

Norma B. Coe and April Yanyuan Wu, May 2014

Differential Mortality and Retirement Benefits in the Health and Retirement Study Barry P. Bosworth and Kathleen Burke, April 2014

Adding Employer Contributions to Health Insurance To Social Security's Earnings and Tax Base

Karen E. Smith and Eric Toder, April 2014

All working papers are available on the Center for Retirement Research website (http://crr.bc.edu) and can be requested by e-mail (crr@bc.edu) or phone (617-552-1762). 